\title{
Development of male sterile transgenic lines in rice by tapetum specific expression of barnase gene
}

\author{
Pravin Kumar $\cdot$ Kulwinder Kaur $\cdot$ Ram Singh Purty $\cdot$ Madan Mohan $\cdot$ Pradeep Kumar Burma
}

Received: 31 August 2017 / Revised: 17 November 2017 / Accepted: 29 November 2017

(c) Korean Society for Plant Biotechnology

\begin{abstract}
The key to development of barnase-barstar transgene based hybrid seed technology is the availability of tightly regulated tapetum specific promoter, as any leaky expression of the barnase gene leads to several unintended effects. In the present study, we used two different tapetum specific promoters i.e. promoter of the $R T S$ gene isolated from rice cultivar IR64 and the $O s G 6 b$ promoter from japonica rice cultivar Hayayuki to express the barnase gene in rice transgenic lines. While viable male sterile transgenic lines could not be obtained with $R T S$ promoter we could develop single copy male sterile lines when the barnase gene was expressed under the $O s G 6 b$ promoter.
\end{abstract}

Keywords Hybrid seed production, male sterile lines, barnase, barstar, tapetum specific promoter, Oryza sativa

\section{Introduction}

Rice is the second largest food crop after maize being grown globally. The yield of the high yielding varieties (HYVs) obtained during green revolution has reached a plateau and there is a need for newer and better ways to

${ }^{\dagger}$ Both author contributed equally.

P. Kumar ${ }^{\dagger} \cdot$ R. S. Purty

University School of Biotechnology, Guru Gobind Singh Indraprastha

University, Sector-16C, Dwarka, New Delhi-110078, India

K. $\mathrm{Kaur}^{\dagger}$

Department of Plant Molecular Biology, University of Delhi

South Campus, New Delhi-110021, India

M. Mohan (ه)

Department of Plant Molecular Biology University of Delhi South Campus, Benito Juarez Road New Delhi-110021, India e-mail: mohanm98@hotmail.com

P. K. Burma $(\bowtie)$

Department of Genetics, University of Delhi South Campus, Benito Juarez Road, New Delhi-110021, India

e-mail: pburma@south.du.ac.in achieve enhanced crop production (Kropff et al. 1994). Among the limited options available, the principle of heterosis is being exploited for generating hybrids which show approximately $20-30 \%$ increase in yields as compared to the high yielding varieties along with other benefits such as improved physical stability, higher responsiveness to fertilizers and better root penetration etc. (Budar and Pelletier 2001; Kempe and Gils 2011). A prerequisite for hybrid seed production is a robust pollination control system that avoids self-fertilization. The most efficient way of promoting crosspollination in bisexual plants is by using male sterility-restorer system. Cytoplasmic male sterility (CMS) due to spontaneous mutations or from interspecific crosses have been widely exploited for hybrid production in many of agricultural and agronomical crops like maize, rice, wheat, sorghum, rye, Brassica etc. (Yuan and Fu 1995; Budar and Pelletier 2001; Harvey 2004).

In case of rice, the Wild Abortive (WA) - CMS system is the only system being widely used for hybrid seed production mainly in China but also in a few other countries including India since last 50 years (Singh et al. 2015). In order to avoid a situation as witnessed in case of maize T- cytoplasm (1950-1970) in U.S.A., due to the extensive use of a single cytoplasm, scientists are trying to develop alternate systems of pollination control for use in hybrid seed production (Budar and Pelletier 2001; Huang et al. 2014).

The barnase-barstar transgene based hybrid seed production technology has been commercially deployed in crops like Brassica napus (Mariani et al. 1990; 1992). The system utilizes the expression of barnase gene, encoding cytotoxic RNase protein in the tapetum cells to make one of the combiner's male sterile. Seed produced in $\mathrm{F}_{1}$ hybrid is restored by expression of the barstar gene, which is also expressed in the tapetum tissue brought into the $F_{1}$ through the other combiner. In the previous work on developing male sterile lines in tobacco (Mariani et al. 1990; 1992), mustard (Jagannath et al. 2001; Bisht et al. 2004), alfalfa (Rosellini 
et al. 2001), pepper (Liu et al. 2009) and eggplant (Cao et al. 2010), the TA29 promoter from Nicotiana tabacum has been successfully used to drive expression of the barnase gene in tapetum tissue.

In case of rice, several tapetum specific genes have been reported e.g. OsC6 (Tsuchiya et al. 1994; Yokoi et al. 1997), OsRA8 (Jeon et al. 1999), OsRA39 (Ding et al. 2002), OsYY2 (Kuriakose et al. 2009), OsRTS (Luo et al. 2006; Deveshwar et al. 2011), OsIPP3, OsbHLH, OsIPK, OsFbox, OsIPA, (Swapna et al. 2011; Khurana et al. 2012; Khurana et al. 2013), OsSCP1, OsSCP2, and OsSCP3 (Park et al. 2006). Of these, the OsRTS promoter from rice cultivar IR54 has been used to demonstrate the development of male sterile line by expression of the barnase gene under the control of this promoter (Luo et al. 2006). However, this strategy has still not been used for production of hybrid seeds.

In the present report, we summarize our efforts to develop male sterile lines in rice by expressing the barnase gene under tapetum specific RTS promoter (Daveshwar et al. 2011) isolated from $O$. sativa indica rice cultivar IR64 or the promoter $O s G 6 b$ from japonica rice cultivar Hayayuki (Tsuchiya et al. 1994). The RTS gene (LOC_Os01g70440) from $O$. sativa cultivar IR64 is reported to be specifically expressed in the anther tissue (Daveshwar et al. 2011). This observation was based on comparative analysis of root, leaf, seed and anther transcriptome. The specific expression of RTS gene was also validated by real time quantitative PCR analysis and by in situ hybridization. The quantitative PCR analysis carried for pre-meiotic anthers (PMA), meiotic anthers (MA), anthers with single-celled pollen (SCP) and tri-nucleate pollen containing anthers (TPA), showed maximum expression of this gene in TPA stage. Further, based on in situ hybridization, Daveshwar et al. (2011) reported that "RTS exhibited expression in the tapetal layer of anther at trinucleate stage with no expression in the pollen grains. The expression of the gene was restricted to the anther as no expression was seen in lemma and palea".

The $O s G 6 b$ promoter drives the expression of the tapetum specific OsC6 gene (LOC_Os11g37280) a lipid transfer protein (LTP) with lipid binding activity. The encoded protein is required for the development of the tapetal structures; viz., orbicules (i.e. Ubisch bodies) and outer pollen wall, exine (Tsuchiya et al. 1994; Wu and Cheun 2000; Zhang et al. 2010). Expression of OsC6 was reported to be mainly detectable in tapetal cells and faintly in microspores. Silencing of OsC6 impaired the formation of orbicules and pollen wall, causing reduced pollen fertility (Zhang et al. 2010). The promoter of the $O s C 6$ gene called as Osg $6 b$ has been used to drive RNAi cassettes of two rice allene oxide synthase (OsAOS1 and OsAOS2) genes, which led to complete or severe sterility phenotype in $28 \%$ of OsAOS1 and $48 \%$ of OsAOS2 transgenic rice plants during the reproductive growth stage compared with the normal wild type plants (Bae et al. 2010). In the present study, we demonstrate that the promoter Os $G 6 b$ could successfully be used to develop male sterile line in rice, by expression of the barnase gene.

\section{Materials and Methods}

Development of vectors for plant transformation

Two different constructs (named I and II) were developed in the present study (Fig. 1). The construct differed in the
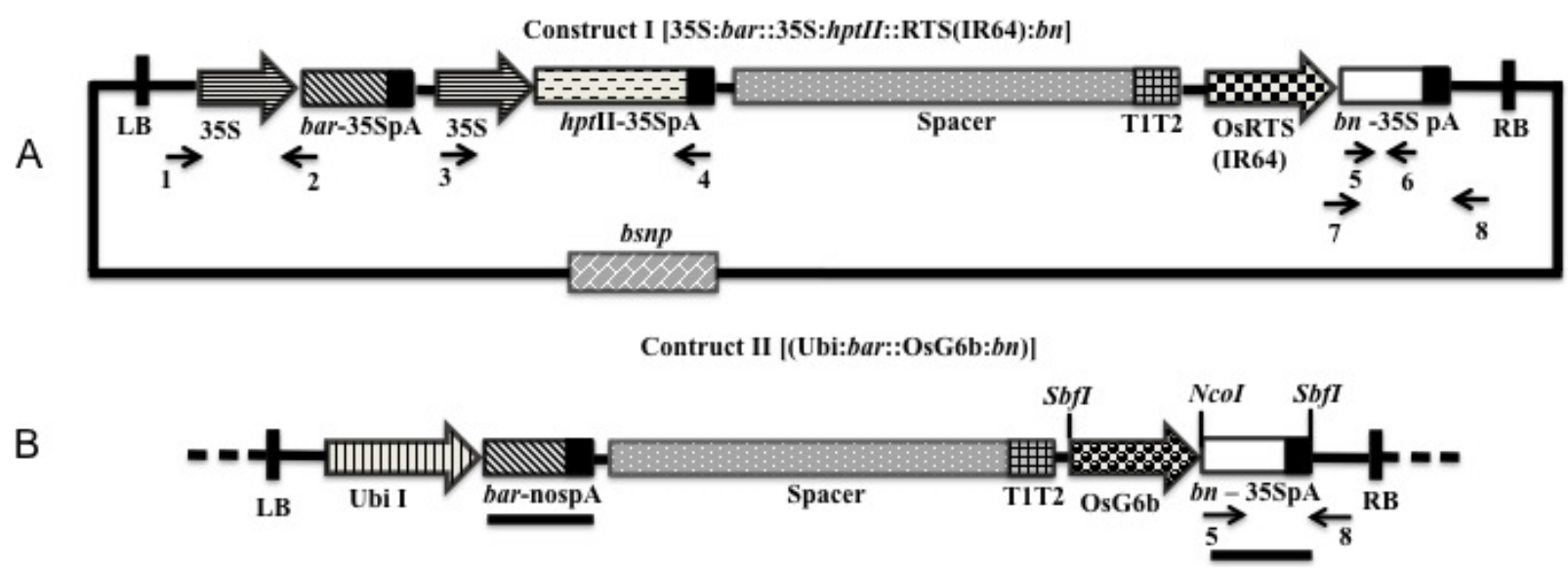

Fig. 1 Schematic representation of the two different constructs used in this study. In construct II, the region outside the T-DNA is the same as construct I. The map also shows the different primers $(\rightarrow)$, restriction enzyme site for genomic DNA digestion and probes (-) for Southern hybridization. [LB - left border end, RB - right border end, $35 S$ - 35S prompter, 35SpA - 35S prompter poly A signal sequence, nospA - nopaline synthase poly A signal sequence, Ubi-I - Ubiquitin promoter. bsnp is barstar gene under its native promoter. hptII and bar are selection marker genes, T1T2 - rho-independent transcription terminator of the rRNA operon of E. coli] 
promoter driving the barnase gene and the selection marker used. The basic backbone of the binary vectors was that of 35S:ALS ${ }^{d m}::$ TA29:bn cassette reported by Ray et al. (2007). Construct I and II carried three and two expression cassettes, respectively between the T-DNA borders. The first expression cassette was that of the barnase gene under the control of two different putative tapetum specific promoters viz. OsRTS (IR64) (construct I) and $O s G 6 b$ (construct II). The second expression cassette was that of a selection marker (useful for both in-vitro and field level selection), where the bar gene was expressed either under 35S (construct I) or Ubiquitin (construct II) promoter. An additional second selection marker $h p t I I$ gene was introduced into construct I under the $35 \mathrm{~S}$ promoter. Polyadenylation signal sequences either from $35 \mathrm{~S}$ (35S $\mathrm{pA}$ ) or from the nopaline synthase (nos $\mathrm{pA}$ ) gene were used in the expression cassette as transcription terminators. In both constructs, the barnase expression cassette was separated from other expression cassettes by a spacer region of $\sim 5.0 \mathrm{~kb}$ DNA fragment which also carried the T1T2 rho-independent transcription terminator of the rRNA operon of $E$. coli as described by Ray et al. (2007). Both the expression cassettes were cloned in binary vector pPZP200. Promoter OsRTS(IR64) $(1.521 \mathrm{~kb})$ was available as a fragment cloned in TOPO vector; pENTR (gift from Dr. Sanjay Kapoor). Promoter $O s G 6 b(1.721 \mathrm{~kb})$ was synthesized commercially by Biolink (USA). The ubiquitin promoter was available as clone in pB4NU plasmid. These binary vectors were developed by routine recombinant DNA techniques. The sequences of the RTS and $O s G 6 b$ promoters are available under Accession No. LOC_Os01g70440 and LOC_Os11g37280, respectively.

Genetic transformation of rice and its growth

O. sativa L. subsp. indica variety Pusa Basmati (PB1) was used for all the genetic transformation experiments. The seeds were obtained from the Indian Agricultural Research Institute, New Delhi, India. Transformation of rice was carried out using secondary calli as explant following the protocol of Hiei et al. (1994) with few modifications. Callus transformed with construct I was selected on hygromycin (50 $\mathrm{mg} / \mathrm{L}$ ) and those transformed with construct II on PPT (2 $\mathrm{mg} / \mathrm{L}$ ). Green shoots of 3-4 cm length obtained on regeneration media were transferred to the rooting medium as described in the protocol. Following rooting, the transgenic plantlets were grown for 2-3 weeks in liquid growth medium described by Yoshida et al. (1976). The hardened transgenic plants were transplanted to soil in a green house maintained at $26 \pm 2^{\circ} \mathrm{C}$ with $16 / 8 \mathrm{~h}$ - light/dark photoperiods.

Genomic DNA isolation, PCR and Southern blot analysis

Leaves from 1-2 month old plants of transformed and untransformed plants were used to isolate genomic DNA (Dellaporta et al. 1983). PCR was performed with $100 \mathrm{ng}$ of template DNA. The PCR reaction mixture $(20 \mu \mathrm{l})$ was contained genomic DNA, 1X Phusion buffer along with 0.5 $\mu \mathrm{M}$ each of gene specific forward and reverse primers, 1.5 $\mathrm{mM} \mathrm{MgCl}_{2}, 3 \%$ DMSO, $200 \mu \mathrm{M}$ dNTPs, and $1 \mathrm{U}$ of Phusion DNA polymerase (NEB). PCR was set at $98^{\circ} \mathrm{C}$ for 30 s of initial denaturation followed by 35 cycles of $\left(98^{\circ} \mathrm{C}\right.$ for $10 \mathrm{~s}$, $62-68^{\circ} \mathrm{C}$ for $20 \mathrm{~s}, 72^{\circ} \mathrm{C}$ for $30 \mathrm{~s}$ ) and a final extension at $72^{\circ} \mathrm{C}$ for $10 \mathrm{~min}$. T-DNA fragments towards the left border (LB) or the right border (RB) was amplified with respective forward and reverse primers as shown in Figure 1. Additionally, for transgenics with construct I the hptII expression cassette and the barnase gene was amplified with primer set 3-4 and 5-6 respectively. The sequences of primers used are given in Supplementary Table 1 .

Southern analysis was performed according to standard protocols. $5 \mu$ g genomic DNA was digested with different sets of restriction enzymes and resolved on $0.7 \%$ agarose gel overnight at $40 \mathrm{~V}$. DNA from the treated gel was transferred overnight by capillary action to the Nylon membrane, using 20X SSC buffer. DNA was UV cross-linked on to the membrane as per the manufacturer's instructions. Probes for hybridization were prepared using a PCR digoxigenin (DIG) probe synthesis Kit (Roche, Switzerland) according to the recommendations of the manufacturer. The hybridized DIG probes were immunodetected with anti-DIG, Fab fragments conjugated to alkaline phosphatase and visualized with the chemiluminescence substrate CSPD by DIG Luminescent

Table 1 Summary of results of genetic transformation of rice with the barnase constructs to generate male sterile lines

\begin{tabular}{|c|c|c|c|c|c|c|c|c|c|}
\hline \multirow{2}{*}{$\begin{array}{l}\text { Construct } \\
\text { name }\end{array}$} & \multirow{2}{*}{$\begin{array}{l}\text { Number of } \\
\text { explants }\end{array}$} & \multirow{2}{*}{$\begin{array}{c}\text { Number of } \\
\text { shoots obtained } \\
\text { in regeneration } \\
\text { medium }\end{array}$} & \multirow{2}{*}{$\begin{array}{l}\text { Selection } \\
\text { medium }\end{array}$} & \multirow{2}{*}{$\begin{array}{l}\text { Plants } \\
\text { transferred in } \\
\text { green house }\end{array}$} & \multicolumn{3}{|c|}{$\begin{array}{l}\text { Phenotype of } T_{0} \text { plants } \\
\text { in green house }\end{array}$} & \multicolumn{2}{|c|}{$\begin{array}{l}\text { Male sterile } \\
\text { /Male fertile }\end{array}$} \\
\hline & & & & & $\begin{array}{c}\text { Plants } \\
\text { analyzed }\end{array}$ & Normal & Abnormal & Fertile & Sterile \\
\hline Construct I & $\sim 900$ & 123 & Hygromycin & 36 & 36 & 11 & 25 & 11 & 0 \\
\hline Construct II & $\sim 900$ & 23 & PPT & 21 & 21 & 21 & 0 & 8 & 13 \\
\hline
\end{tabular}


Detection Kit (Roche, Switzerland) with chemiluminescence visualization machine (ImageQuant LAS 4000, GE healthcare Life science).

Pollen viability test using Fluorescein diacetate (FDA) staining

Pollen grains were collected from untransformed and transformed transgenic plants. For FDA staining, pollen grains were incubated with FDA solution (2.0 mg FDA and 1.71 $\mathrm{g}$ sucrose dissolved in $10 \mathrm{ml}$ distilled water) for 10 minute and observed under fluorescence microscope using GFP filters (Excitation- $489 \mathrm{~nm}$ and emission-511 nm) (Heslop-Harrison and Heslop-Harrison 1970).

\section{Results}

Development of transgenics in rice with construct I

Transformation of rice cultivar PB1 was carried with construct I (Fig. 1) in which the barnase gene was under the control of the RTS (IR64) promoter as described in the Materials and Methods. The construct also carries selection marker for resistance to PPT (bar) and hygromycin (hptII) gene. Out of around 900 explants used in three independent transformation experiments, 123 calli regenerated into shoots following three rounds of selection on hygromycin $(50 \mathrm{mg} / \mathrm{l})$ (Table 1). Of the 123 regenerated shoots, only 36 of them developed to a stage where they could be transferred to soil under green house condition. Rest of the regenerated shoots died during further growth or did not root. On transfer to soil, two distinct phenotypes of the plants were observed. 11 transgenic plants was observed to be phenotypically normal in terms of overall growth and morphology, which was comparable to that of untransformed control plants (compare Fig. 2B to 2A). 25 transgenic plants were phenotypically abnormal, stunted in growth and finally died (Fig. 2C). All the plants with normal phenotype were observed to be male fertile, formed pollen and set seeds on selfing. All the available transgenic lines with normal as well as abnormal phenotypes were characterized for the presence of four different parts of the T-DNA cassettes by PCR. Primers 1 and 2 (Fig. 1A) were designed to amplify the 35S promoter adjacent to $\mathrm{LB}$, while primers 3 and 4 were designed to amplify the hptII expression cassette. Primer set 5-6 and 7-8 was designed to amplify the barnase gene adjacent to the RB. It was observed that all the 11 transgenic lines with normal phenotype lacked the barnase gene. However, all these 11 lines showed the presence of

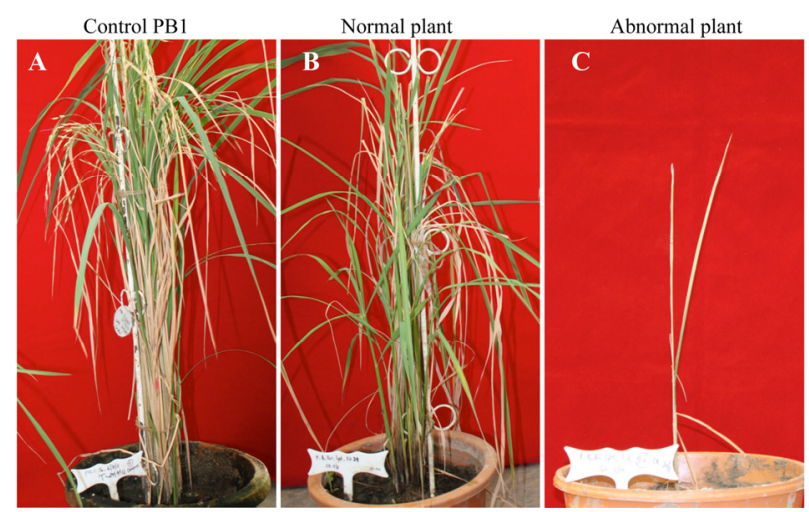

Fig. 2 Phenotype of untransformed PB1 rice line (A) and lines transformed with construct I (B and $\mathrm{C}$ ), after around two months of growth in soil. Two kinds of transgenic lines were observed with normal (B) and abnormal (C) phenotypes. All abnormal plants died subsequently

the $h p t I I$ gene cassette. On the other hand, phenotypically abnormal plants, which subsequently died, showed the presence of both the hptII and barnase gene. Thus, no proper barnase lines could be obtained with construct I. The results are summarized in Supplementary Table 2 and a representative gel picture is presented in Supplementary Fig. 1.

Development of male sterile transgenic rice line with construct II

In construct II (Fig. 1B), the promoter $O s G 6 b(1.721 \mathrm{~kb})$ was used to drive the expression of barnase gene. The construct also carries selection marker for resistance to PPT (bar) gene. A total of 21 independent PPT resistant lines were obtained from $\sim 900$ explants that were initially transformed (Table 1). All 21 putative $\mathrm{T}_{0}$ transgenic lines showed normal phenotype when grown in the green house (Fig. 3A). Out of these 21 lines, 13 were male sterile and unable to set seeds after selfing (Table 2). Anthers of most of the flowers had no pollen grain and even if these are formed, they were deformed and not viable (Fig. 3C). Seed set was observed in the other 8 transgenic lines that turned out to be male fertile. The presence of barnase gene was checked in all the $\mathrm{T}_{0}$ transgenic lines by PCR using primer pair 5 and 8 (Fig. 1B). It was observed (Fig. 4A) that all male sterile lines (e.g. line no. 3, 4, 5, 7, 9, 10, 14, 16, 18, 19, 20 and 21) showed the presence of the barnase gene while the fertile lines lacked the same (e.g. line no. 1, 2, 8, 15 and 17).

In order to evaluate the number of transgene copies in the independent male sterile lines Southern blot analysis was carried out. Genomic DNA digested with NcoI enzyme 
Table 2 Analysis of $\mathrm{T}_{0}$ transgenic lines from construct II showing T-DNA copy number of integration, empty and filled spikelets after selfing

\begin{tabular}{ccccc}
\hline S.N. & Line Number & Copy number of transgene & Number of Filled spikelet & Number of Empty Spikelet \\
\hline 1. & $1 \mathrm{~A}$ & No & 1466 & 650 \\
2. & $3 \mathrm{~B}$ & Double & Zero & 3544 \\
3. & $4 \mathrm{C}$ & Double & Zero & 3100 \\
4. & $5 \mathrm{~A}$ & Double & Zero & 2155 \\
5. & $6 \mathrm{~A}$ & Double & Zero & 3060 \\
6. & $7 \mathrm{~A}$ & Single & Zero & 1193 \\
7. & $9 \mathrm{~A}$ & Single & Zero & 1136 \\
8. & $10 \mathrm{~A}$ & Single & Zero & 3047 \\
9. & $14 \mathrm{~A}$ & Not Analyzed & Zero & 707 \\
10. & $16 \mathrm{~A}$ & Not analyzed & Zero & 1070 \\
11. & $18 \mathrm{~A}$ & Single & Zero & 1900 \\
12. & $19 \mathrm{~A}$ & Single & Zero & 675 \\
13. & 20D & Single & Zero & NA \\
14. & 21B & Double & Zero & 1000 \\
15. & PB1 & Nontrol) & 1481 & 671 \\
\hline
\end{tabular}

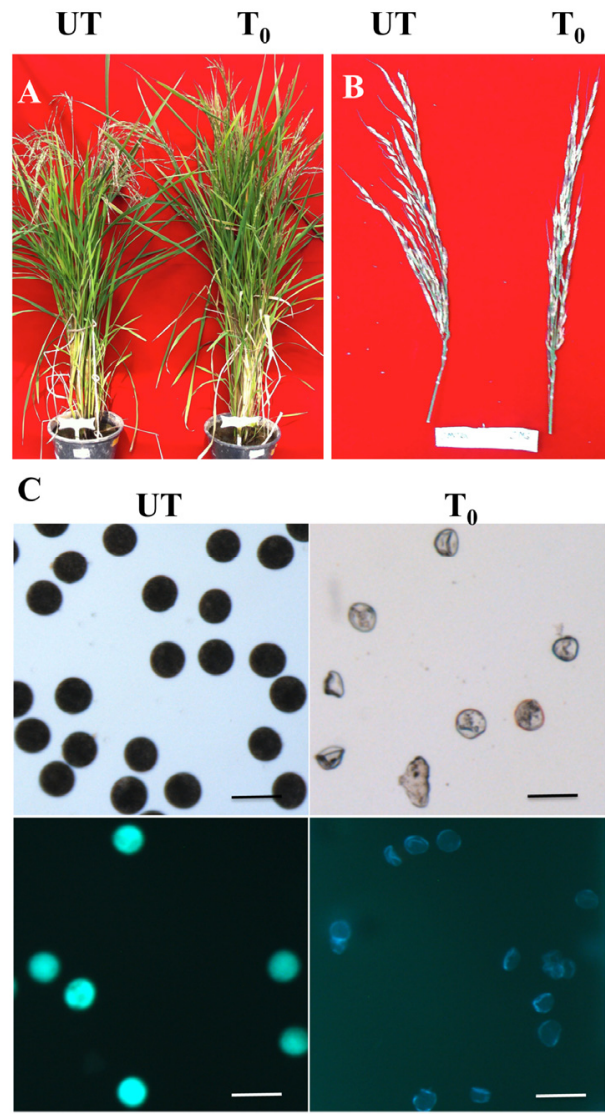

Fig. 3 Phenotype of untransformed and $T_{0}$ transgenic line with construct II. (A) Similar phenotype of transgenic barnase line. (B) Same panicle length of the transgenic barnase line. (C) The barnase line showing deformed and starch devoid pollen grains in FDA staining. (Scale bar $=10 \mu \mathrm{m}$ )

was probed with barnase gene specific probe (Fig. 1B) to identify the T-DNA - genomic DNA junction sequence towards the RB (Fig. 4B). Similarly, genomic DNA digested with Sbfl enzyme was probed with bar gene to identify the T-DNA - genomic DNA junction sequence towards the LB (Fig. 4C). Line 1 (a male fertile line) and untransformed plant of PB1 were also used as control in this experiment. Southern hybridization showed the integration of the transgene in all the male sterile lines. Line 1 and untransformed plant of PB1 (control) did not hybridize with the probe. Line numbers $7,9,10,18,19$ and 20 showed a single copy of the T-DNA cassette in the genome. The rest of the sterile lines had two copies of T-DNA cassette. The male sterile lines were crossed with untransformed PB1 line. Appropriate number of seeds was obtained after pollination with normal PB1. Limited analysis of $T_{1}$ progeny obtained from the $T_{0}$ lines showed the presence of both Basta resistance and sensitive lines, which were male sterile and fertile, respectively.

\section{Discussion}

The present work was initiated to develop male sterile line in rice by expression of the barnase gene in a tapetum specific manner. Taking cue from the work of Luo et al. 2006, the promoter of RTS gene, was used to drive the expression of the barnase gene. In the work by Luo et al. (2006), $1.2 \mathrm{~kb}$ promoter isolated from rice cultivar IR54 was used to express the barnase gene in rice as well as in creeping bent grass and Arabidopsis, which led to the development of male sterility. In case of rice, they reported that 21 of the 37 transgenic rice plants developed were male sterile. They further showed that these lines could be fertilized by wild type pollen to produce normal seed set.

However in the present study, we failed to develop male sterile lines with a similar promoter isolated from the rice 

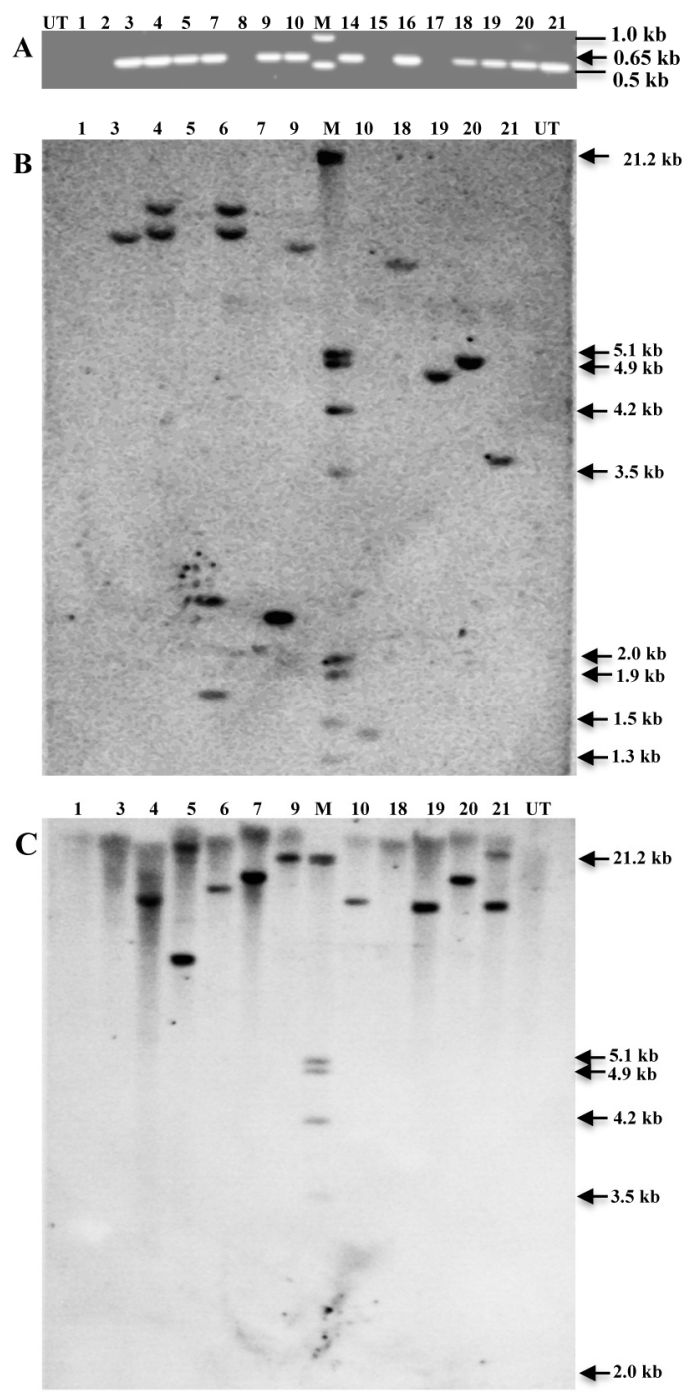

Fig. 4 Analysis of integration of transgenes in independent $T_{0}$ lines obtained in construct II by PCR analysis (A) and Southern blot hybridization (B and $\mathrm{C}$ ). For Southern blots analysis of T-DNA genomic DNA junction (B) towards RB was done by digestion of genomic DNA with NcoI and hybridized with barnase gene probe, while (C) junction towards LB was done by digestion of genomic DNA with SbfI and hybridized with bar gene probe. [UT- untransformed line, Lane 1-21 - different independent lines obtained from construct II, M- DNA Marker]

cultivar IR 64. From our observations it is obvious that the RTS promoter in the current study is not tightly regulated when transgenics are developed with the construct I. As Barnase protein is cytotoxic, expression of the gene in other tissues during regeneration and growth leads to lethality. Thus lines where the barnase gene has been knocked out were preferentially selected for. This has also been observed in earlier studies (Jagannath et al. 2001, Ray et al. 2007). Further, deletion of parts of T-DNA cassettes have been reported in earlier studies (Rai et al. 2007; Zhang et al. 2008; Rawat et al. 2011) although the selection cassette was placed towards the right border to ensure selection of lines with complete transfer of T-DNA. The present observations indicate that the RTS promoter lost its tapetum specific characteristics when incorporated in the T-DNA construct. This could be due to inherent differences in the two promoters isolated from the two different rice cultivars.

Comparison of the DNA sequence of the RTS promoter isolated from the rice cultivar IR54 (Luo et al. 2006) and IR64 (Deveshwar et al. 2011) showed the insertion of a $44 \mathrm{bp}$ stretch (at -1005 to -962 position) apart from 3 substitutions and 3 single base insertions. The promoter also carried an additional 264 bp at its $5{ }^{\prime}$ end. The 5 ' UTR of RTS (IR 64) and RTS (IR 54) were also different, the first being of $14 \mathrm{bp}$ and the later of $78 \mathrm{bp}$. These differences may have led to the loss of tight regulation at the RTS promoter making the promoter leaky. Further, in the study by Deveshwar et al. (2011), the activity of the gene was mainly studied by comparative analysis of the transcriptome and in situ hybridization studies. Strategies like comparative analysis of transcriptome and in situ hybridization, analyses activity of the promoter at its original genomic location, whereas studies done by developing transgenics, analyses activity of promoters at ectopic genomic locations. In the later case, a promoter can be influenced by the position of integration that can lead to leaky expression. Thus from the present study it seems that the RTS promoter from IR64 is not tightly regulated in transgenic lines and thus not useful in developing male sterile lines. However, a comparative study between the RTS promoters isolated from rice cultivars IR64 and IR54 using reporter genes like $\beta$-glucuronidase would have to be done to get a more specific answer.

One could also argue that the leaky expression of the RTS promoter is due to the presence of the constitutive CaMV35S promoter in its near vicinity. It has however, been unequivocally demonstrated in earlier studies that the $5 \mathrm{~Kb}$ spacer fragment (Jagannath et al 2001, Ray et al 2007) between the selection marker and the passenger gene insulates the tapetum specific promoter from the enhancing activity of the CaMV35S promoter.

Male sterile lines in rice could be developed with construct II where in the tapetum specific promoter $O s G 6 b$ was used to drive the expression of the barnase gene. Although this promoter has been used earlier to express RNAi constructs directed against allene oxide synthase (Bae et al. 2010) this is the first report of developing a barnase gene based male sterile line in rice using this promoter. We currently have 3 independent male sterile lines that have a single copy of 
T-DNA insertion. After testing its stability over a few generations, these lines can be used for introgression of the male sterile phenotype into an appropriate combiner. Further, restoration of these lines by crossing them to lines expressing barstar gene needs to be evaluated.

\section{Acknowledgements}

We thank Prof. Deepak Pental for his intellectual inputs and Prof. Sanjay Kapoor for providing the construct with the OsRTS (IR64) promoter. PK would like to thank UGC, New Delhi for Dr. D.S. Kothari post-doctoral fellowship [File no. 13-444/2011(BSR)], SERB-DSR for Young Scientist Fast track grant (SB/YS/LS-104/2014). The work was also supported by grants to MM under CSIR- NIMITLI grant (File no. 5/258/53/2006), University of Delhi R\&D grant and DST-PURSE grant. KK is thankful to CSIR, New Delhi for JRF and SRF (File no. 09/045(0824)/2009-EMR-1).

\section{Author contributions}

MM, PKB, PK, KK conceived and designed the experiments. Experiments with construct I (RTS(IR64):bn) construct was carried out by $\mathrm{KK}$ while experiments with construct II $(O s G 6 b: b n)$ was conducted by PK. PK, MM, PKB, RSP wrote the manuscript.

\section{References}

Bae HK, Kang HG, Kim GJ, Eu HJ, Oh SA, Song JT, Chung IK, Eun MY, Park SK (2010) Transgenic rice plants carrying RNA interference constructs of AOS (allene oxide synthase) genes show severe male sterility. Plant Breeding 129(6): 647-651

Bisht NC, Jagannath A, Gupta V, Burma PK, Pental D (2004) A two gene - two promoter system for enhanced expression of a restorer gene (barstar) and development of improved fertility restorer lines for hybrid seed production in crop plants. Molecular Breeding 14(2):129-144

Budar F, Pelletier G (2001) Male sterility in plants: Occurrence, determinism, significance and use. Comptes Rendus de l'Academie Des Sciences - Serie III 324(6):543-550

Cao B, Huang Z, Chen G, Lei J (2010) Restoring pollen fertility in transgenic male-sterile eggplant by Cre/loxp-mediated sitespecific recombination system. Genetics and Molecular Biology 33(2):298-307

Dellaporta S L, Wood J, Hicks JB (1983) A Plant DNA Mini preparation : Version II. Plant Mol. Biol. Report 1:19-21

Deveshwar P, Bovill WD, Sharma R, Able JA, Kapoor S (2011)
Analysis of anther transcriptomes to identify genes contributing to meiosis and male gametophyte development in rice. BMC Plant Biology 11(1):78

Ding Z, Wu X, Wang T (2002) The rice tapetum-specific gene RA39 encodes a type I ribosome-inactivating protein. Sexual Plant Reproduction 15(4):205-212

Harvey MJ (2004) The use of cytoplasmic male sterility for hybrid seed production. In: Molecular Biology and Biotechnology of Plant Organelles: Chloroplasts and Mitochondria (Daniel H and Chase C):623-634

Heslop-Harrison J, Heslop-Harrison Y (1970) Evaluation of pollen viability by enzymatically induced fluorescence, intracellular hydrolysis of fluorescein diacetate. Stain Technol 145:115-120

Hiei Y, Ohta S, Komari T, Kumashiro T (1994) Efficient transformation of rice (Oryza sativa L.) mediated by Agrobacterium and sequence analysis of the boundaries of the T-DNA. The Plant Journal: For Cell and Molecular Biology 6(2):271-282

Huang J-Z, E Z-G, Zhang H-L, Shu Q-Y (2014) Workable male sterility systems for hybrid rice: Genetics, biochemistry, molecular biology, and utilization. Rice 7(1):13

Jagannath A, Bandyopadhyay P, Arumugam N, Gupta V, Burma PK, Pental D (2001) The use of a Spacer DNA fragment insulates the tissue-specific expression of a cytotoxic gene (barnase) and allows high-frequency generation of transgenic male sterile lines in Brassica juncea L. Molecular Breeding $8(1): 11-23$

Jeon JS, Chung YY, Lee S, Yi G H, Oh BG, An G (1999) Isolation and characterization of an anther-specific gene, RA8, from rice (Oryza sativa L.). Plant Molecular Biology 39(1):35-44

Kempe K, Gils M (2011) Pollination control technologies for hybrid breeding. Molecular Breeding 27(4):417-437

Khurana R, Kapoor S, Tyagi A K (2012) Anthology of Anther/ Pollen-Specific Promoters and Transcription Factors. Critical Reviews in Plant Sciences 31(5):359-390

Khurana R, Kathuria H, Mukhopadhyay A, Kapoor S, Tyagi AK (2013) A 286 bp upstream regulatory region of a rice antherspecific gene, OSIPP3, confers pollen-specific expression in Arabidopsis. Biotechnology Letters 35(3):455-462

Kropff MJ, Cassman KG, Peng S, Setter TL, Mathews RB (1994) Quantitive understanding of rice yield potential. In: K.G. Cassman (Editor), Breaking the Yield barrier. International Rice Research Institute, Los Banos, Philippines: 21-38

Kuriakose B, Arun V, Gnanamanickam SS, Thomas G (2009) Tissue-specific expression in transgenic rice and Arabidopsis thaliana plants of GUS gene driven by the $5^{\prime}$ regulatory sequences of an anther specific rice gene YY2. Plant Science 177(5):390-397

Liu J, Yu Y, Lei J, Chen G, Cao B (2009) Study on AgrobacteriumMediated Transformation of Pepper with Barnase and Cre Gene. Agricultural Sciences in China 8(8):947-955

Luo H, Lee JY, Hu Q, Nelson-Vasilchik K, Eitas TK, Lickwar C, Kausch AP, Chandlee JM, Hodges T K (2006) RTS, a rice anther-specific gene is required for male fertility and its promoter sequence directs tissue-specific gene expression in different plant species. Plant Molecular Biology 62(3):397-408 
Mariani C, Beuckeleer M D, Truettner J, Leemans J, Goldberg RB (1990) Induction of male sterility in plants by a chimaeric ribonuclease gene. Nature 347(6295):737-741

Mariani C, Gossele V, De Beuckeleer M, De Block M, Goldberg R. B, De Greef W, Leemans J (1992) A chimaeric ribonucleaseinhibitor gene restores fertility to male sterile plants. Nature 357:384-387

Park J-I, Hakozaki H, Endo M, Takada Y, Ito H, Uchida M, Okabe $\mathrm{T}$, Watanabe M (2006). Molecular characterization of mature pollen-specific genes encoding novel small cysteine-rich proteins in rice (Oryza sativa L.). Plant Cell Reports 25(5): 466-74

Rai M, Datta K, Parkhi V, Tan J, Oliva N, Chawla HS, Datta SK (2007) Variable T-DNA linkage configuration affects inheritance of carotenogenic transgenes and carotenoid accumulation in transgenic indica rice. Plant Cell Reports 26(8):1221-31

Ray K, Bisht NC, Pental D, Burma PK (2007) Development of barnase/barstar transgenic for hybrid seed production in Indian oilseed mustard (Brassica juncea L. Czern and Coss) using a mutant acetolactate synthase gene conferring resistance to imidazolinone-based herbicide 'Persuit'. Current Science 93:1390-1396

Rawat P, Singh AK, Ray K, Chaudhary B, Kumar S, Gautam T, Kanoria S, Kaur G, Kumar P, Pental D, Burma PK (2011) Detrimental effect of expression of Bt endotoxin CrylAc on in vitro regeneration, in vivo growth and development of tobacco and cotton transgenics. Journal of Biosciences 36(2): 363-376

Rosellini D, Pezzotti M, Veronesi F (2001) Characterization of transgenic male sterility in alfalfa. Euphytica 118(3):313-319
Singh SK, Bhati PK, Sharma A, Sahu V (2015) Super hybrid rice in China and India: Current status and future prospects. Int.J.Agric. Biol. 17:221-232

Swapna L, Khurana R, Vijaya Kumar S, Tyagi AK, Rao KV (2011) Pollen-specific expression of oryza sativa indica pollen allergen gene (OSIPA) promoter in rice and arabidopsis transgenic systems. Molecular Biotechnology 48(1):49-59

Tsuchiya T, Toriyama K, Ejiri SI, Hinata K (1994) Molecular characterization of rice genes specifically expressed in the anther tapetum. Plant Molecular Biology 26(6):1737-1746

Wu HM, Cheun AY (2000) Programmed cell death in plant reproduction. Plant Molecular Biology 44(3):267-81

Yokoi S, Tsuchiya T, Toriyama, K., Hinata K (1997) Tapetumspecific expression of theOsg6B promoter- $\beta$-glucuronidase gene in transgenic rice. Plant Cell Reports 16:363-367

Yoshida S, Forno DA, Cock JH, Gomez KA (1976) Routine procedure for growing rice plants in culture solution. In: Laboratory manual for physiological studies of rice, International Rice Research Institute, Manila, The Philippines: 61-66

Yuan LP, Fu XQ (1995) Technology of hybrid rice production. Rome: FAO:84

Zhang D, Liang W, Yin C, Zong J, Gu F, Zhang D (2010) OsC6, encoding a lipid transfer protein, is required for postmeiotic anther development in rice. Plant Physiology 154(1):149-162

Zhang J, Cai L, Cheng J, Mao H, Fan X, Meng Z, Chan KM, Zhang H, Qi J, Ji L, Hong Y (2008) Transgene integration and organization in cotton (Gossypium hirsutum L.) genome. Transgenic Research 17(2):293-306 